How to cite: Nouaceur, Z., Murarescu, O. (2019) Comparative Analysis on the Rainfall Variability in two Regions of North Africa: the Moroccan Middle Atlas and the Northern East of Tunisia (PHC Maghreb Transversal Project 2017- 2020). 2019 "Air and Water - Components of the Environment" Conference Proceedings, Cluj-Napoca, Romania, p. 121-128, DOI: 10.24193/AWC2019_12.

\title{
COMPARATIVE ANALYSIS ON THE RAINFALL VARIABILITY IN TWO REGIONS OF NORTH AFRICA: THE MOROCCAN MIDDLE ATLAS AND THE NORTHERN EAST OF TUNISIA (PHC MAGHREB TRANSVERSAL PROJECT 2017- 2020)
}

\section{Zeineddinne NOUACEUR ${ }^{1}$, Ovidiu MURARESCU ${ }^{2}$ M}

DOI: 10.24193/AWC2019_12

\begin{abstract}
To determine to what extent climate change affects the rainfall recorded on the southern Mediterranean basin, a trend analysis is proposed. This study is based on the chronological graphic method of processing information (MGCTI) of type "Matrice Bertin". Results show an extreme variability of the precipitations and a severe drought, especially for Morocco, observed since 1970s. Finally, a gradual return to humid conditions was observed from the beginning of the 2002 in Tunisia and since 2008 in Morocco.
\end{abstract}

Keywords: climate change, trend of precipitation, drought, rain return, Maghreb

\section{INTRODUCTION}

Climate change is now widely recognized by the scientific community (IPCC, 2013). In its latest report, the IPCC assesses the average trend in global temperature over the period $1880-2012$ at $+0.85^{\circ} \mathrm{C}$ with an uncertainty between $0.65^{\circ} \mathrm{C}$ and $1.06^{\circ} \mathrm{C}$. The increase over the last decade 2003-2012 amounts to $+0.78^{\circ} \mathrm{C}$ (for a minimum of $0.72^{\circ}$ $\mathrm{C}$ and a maximum of $0.85^{\circ} \mathrm{C}$ ). The increase of minimum temperatures in the South of the Mediterranean basin is higher, sharper and affects all regions (Nouaceur et al., 2013).

The Mediterranean area, acknowledged as one of the hot spots of the climate change, should undergo - until 2100 - an average temperature increase of 3 to $4^{\circ} \mathrm{C}$, a decrease in precipitations and an intensification of the extreme events (IPCC, 2007). The combined effect of the climatic change and of the anthropic impact should trigger a lack of water for about 290 million people.

Most of studies related to the evolution of the precipitation show that climate change is manifested by an intensification of hydrological cycle and a recurrence of extreme events over last decades (New et al. 2001; Christensen et al. 2007; Massei et al., 2007; Tramblay et al., 2012). These studies also bring to light that changes will occur mostly

\footnotetext{
${ }^{1}$ UMR IDÉES CNRS 6226, Rouen University, 1 Rue Thomas Becket 76821, Mont Saint-Aignan Cedex France, zeineddine.nouaceur@univ-rouen.fr

${ }^{2}$ Valahia University, Department of Geography, Târgovişte (Romania), ovidiu_murarescu@yahoo.com
} 
as far as precipitation repartition worldwide is concerned, resulting an increase in precipitations in the equatorial areas and at the Poles, at the expense of the Mediterranean and of the dry and temperate tropical areas.

During the last years, rains generated severe floods around the world. The monsoon rains were extremely strong in India in 2008 and particularly devastating Pakistan in 2009. In 2010, more than forty cities in the north-eastern side of Australia have been affected by historic floods (200,000 people were affected). In 2013, the movement speed and violence of the Indian monsoon have been exceptional - more than 5,000 people were killed in deadly flooding (Bossy, 2013). Moreover, in February 2014, in England was observed the worst floods ever recorded for two centuries and wettest winter from over 250 years (Corner, 2014). Finally, in 2017, more than 1,200 people have died and 40 million affected by the devastation across India, Bangladesh and Nepal as a result of flooding (caused by heavy monsoon rains).

The study undertaken on about 80 years of measurements recorded at the meteorological stations from the Middle Atlas (Morocco) and its margins (Fig. 1), aims to highlight that after many years of drought, one can note a return towards more humid weather conditions. The signs of change are very significant in the recent years. These rains also seem to be the norm nowadays for the whole of the Maghreb region. This return of the rains, if confirmed, could mark the end of several decennia of recurrent droughts, and could announce a possible durable return to "normal" weather. This hypothesis is supported by the highlighted impact of the different world climate oscillations (North-Atlantique - Oscillation; El Nino Southern Oscillation) on the whole of the continents and especially on the African continent (López-Moreno, 2011). These cyclic oscillations whose significance is still the object of many debates could explain the variability of the precipitations in Morocco, and could support the hypothesis of a return of the rains, marking the end of the years of droughts. The forecasts vary from one model to the next, but an increase in precipitations and a multiplication of the extreme climatic events could find its place in this global dynamic of climate change (IPCC, 2007).

Regarding Algeria, the situation of Tunisia, the situation is less clear since the most of areas range between arid and semi-arid conditions. However, this trend is confirmed by an increase in flood. A good example can be illustrated by Sfax city which is flooded twice in 1969 and 1982. In spite of the major managements performed in 1984, the city is again submerged by waters in 2009 and 2013 (Daoud, 2013).

\section{DATA AND METHODS}

The data of this study concerns two countries (Morocco and Tunisia). For Morocco, the chosen area is the Middle Atlas (5 stations). In Tunisia, we selected 7 stations located in north-east of the country (Fig. 1).

In order to determine the trend of rainfall, we use chronological graphic method of information processing (MGCTI) of type "Bertin Matrix" (Nouaceur et al., 2013) applied to rainfall. This method aims first to analyze the distribution in space and in time and second to determinate the changes in rainfall cycles. 
A classification per year relative to limit values (Q1, Q2, median, Q3 and Q4) is performed for all stations and for the full-time series (Table 1). The years with cumulative rainfall lower than the limit value of 1 (Q1) are considered very dry. Those situated between Q1 and Q2 are considered dry. Years having rainfall height between the second quintile and its median are normal with a dry trend. Between the median interval and Q3, the years are normal with a wet trend. Between Q3 and Q4, years are classified as wet. Finally, years with cumulative rainfall higher than Q5 are considered very wet.

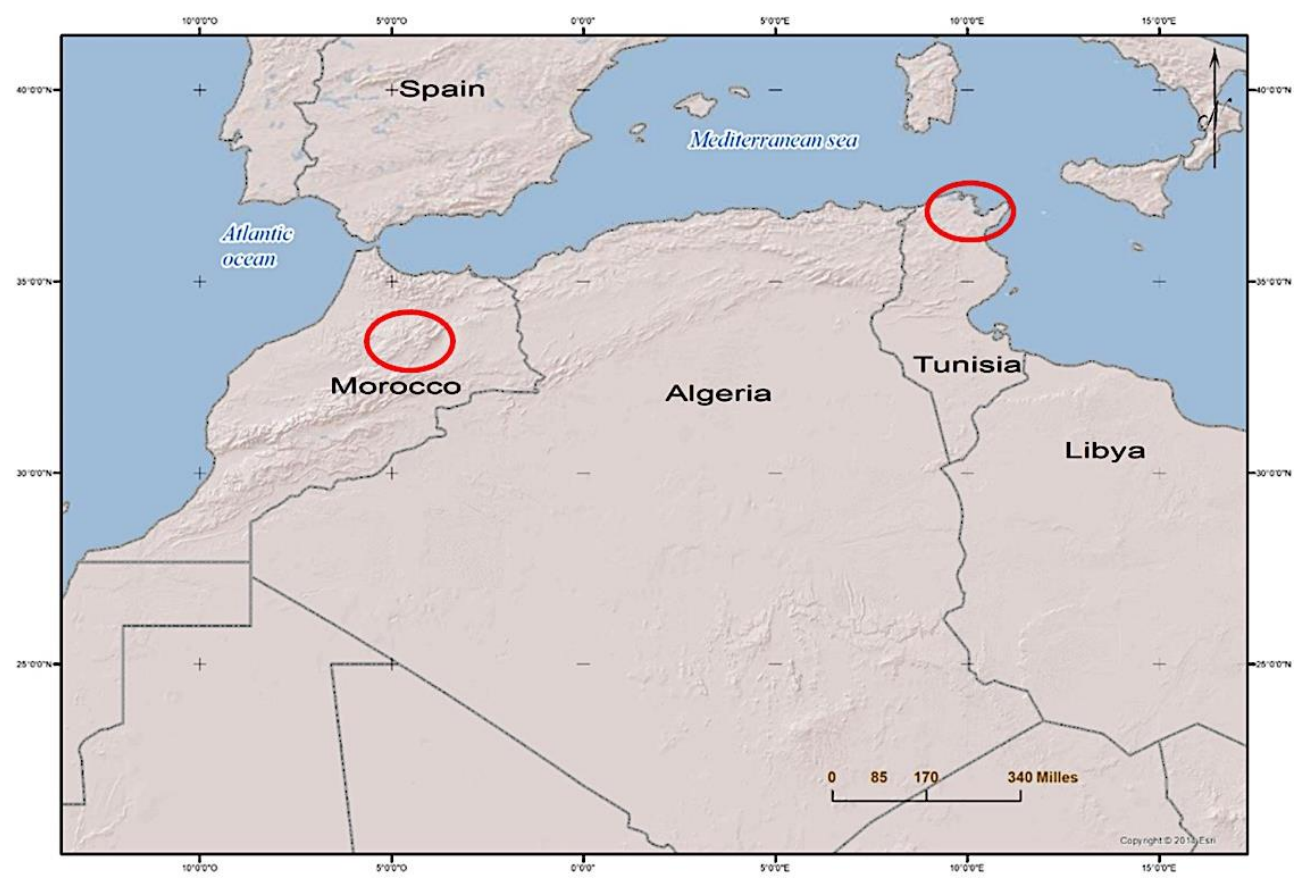

Fig. 1. Map of study area localization

After this first step, a recording of values through a range of colours is done (the varying colour depending on the position of the rainfall cumulative compared to the limit values).

This first treatment is followed by a procedure for reordering (permutations of columns) in order to obtain a classification that show a homogeneous structure coloured - Bertin matrix. This procedure allows us to visualize the evolution of the rainfall according to two dimensions - space and time.

To determine the ruptures and the characteristic periods, a second procedure is to be performed. It is to assign a number ranging from 1 (very dry year) to 5 (very humid) following the characters already determined and allocated to each year.

The sum of the numbers of all stations for each year is centred reduced, allowing thus obtain an index that varies from +1.80 for a very humid year to -1.80 for a very dry year. 
The result is projected on a graph to show first the rainfall variability on a regional scale and second to determine the dates of breaks and changing trend.

Table 1. Features of studied stations

\begin{tabular}{|c|c|c|c|c|c|c|c|}
\hline \multicolumn{8}{|c|}{ Tunisia } \\
\hline Stations & Sejenane Délégation & Ras El Ain & Djebel Essama & Chaab Eddoud & Koussat 비 Bey & Tinja Her & Sidi Salem \\
\hline Average & 839,74 & 524,81 & 717,70 & 612,27 & 459,15 & 599,81 & 669,92 \\
\hline Median & 816,40 & 506,70 & 727,50 & 579,50 & 442,50 & 585,20 & 668,10 \\
\hline QI & 659,00 & 362,00 & 510,20 & 497,10 & 305,30 & 478,30 & 530,20 \\
\hline Q2 & 786,50 & 479,95 & 685,60 & 531,20 & 433,50 & 555,30 & 623,55 \\
\hline Q3 & 885,50 & 563,95 & 771,41 & 640,20 & 484,50 & 642,70 & 709,00 \\
\hline Q4 & 1075,00 & 666,20 & 862,60 & 775,10 & 614,40 & 722,00 & 807,40 \\
\hline $\operatorname{Max}$ & 1287,50 & 843,20 & 1198,50 & 873,80 & 822,00 & 881,70 & 977,70 \\
\hline Min & 402,00 & 232,30 & 323,80 & 338,70 & 205,80 & 243,90 & 404,40 \\
\hline Standard deviation & 218,84 & 148,85 & 194,67 & 141,02 & 142,49 & 146,70 & 152,94 \\
\hline \multicolumn{8}{|c|}{ Morocco } \\
\hline Stations & Ifrane & Fez & Taza & Sefrou & Meknes & & \\
\hline Average & 947,00 & 474,49 & 586,35 & 533,98 & 548,98 & & \\
\hline Median & 878,60 & 466,80 & 534,70 & 523,50 & 527,30 & & \\
\hline QI & 720,50 & 364,60 & 426,50 & 368,20 & 401,80 & & \\
\hline Q2 & 832,40 & 433,50 & 496,40 & 480,90 & 496,30 & & \\
\hline Q3 & 979,70 & 504,90 & 557,60 & 592,83 & 553,30 & & \\
\hline Q4 & 1143,90 & 622,49 & 752,40 & 701,60 & 696,80 & & \\
\hline $\operatorname{Max}$ & 1865,70 & 761,10 & 1203,30 & 921,68 & 1147,40 & & \\
\hline Min & 583,20 & 206,90 & 328,20 & 227,49 & 181,50 & & \\
\hline Standard deviation & 269,82 & 141,84 & 196,32 & 170,08 & 190,58 & & \\
\hline
\end{tabular}

\section{RESULTS}

For Tunisia, the rainfall values recorded in the Northern Tunisia shows an important variability (Fig. 2). The MGCTI matrix also reveals different trends:

- A wet phase between 1970 and 1976.

- A long dry period for 25 years (1977-2001) interspersed with a short-wet period (1979-1980, 1990-1992, 1996-1997). During this phase, negative indices were higher than -95 (partial dryness) for 11 years.

- A wet period between the years 2002 and 2011, during which only year 2008 has recorded a negative index.

For Morocco, the application of the chronological graphic method to the rainfall data recorded at the Middle Atlas and its margins shows a structure more organized with better delimited phases of trend:

- A wet phase between 1970 and 1980, the annual rains are marked by an upward trend. The clues on this first period are all positive except for 1974 (-0.17). During five years, an index higher than +1 is noted. 
- From 1981, a long drought which lasted twenty-seven brand this territory. Reduced centered differences appear negative values reaching -1 for 9 years. Finally,

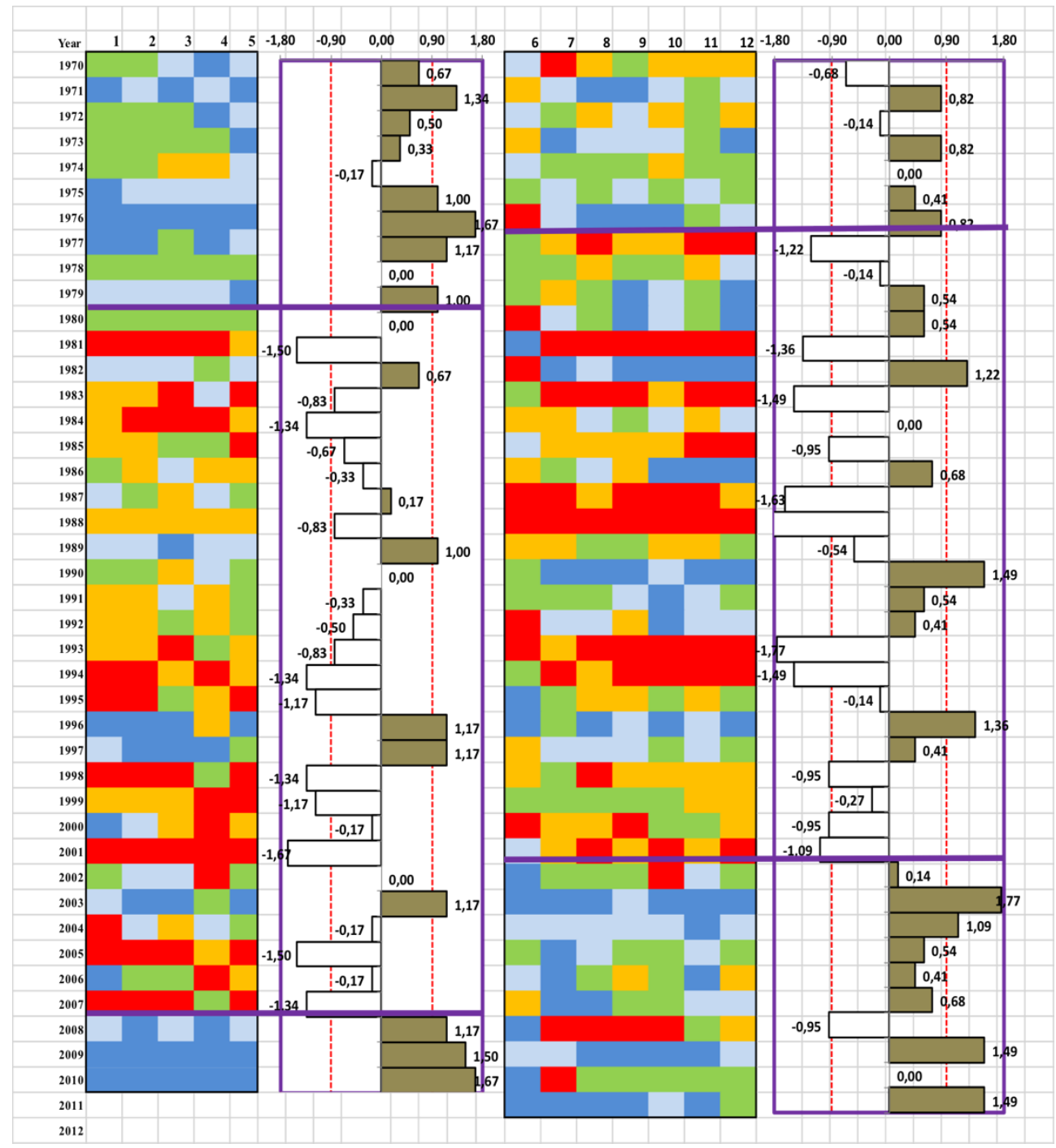



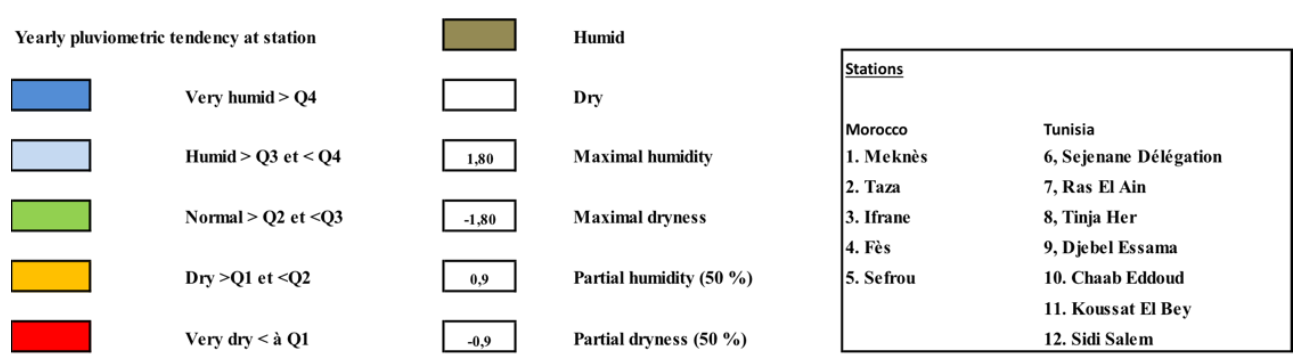

Fig. 2. Chronological graphic method of information processing (MGCTI) (Morocco and Tunisia, 1970-2011)

for twenty-seven years of this period, only 6 years fall into the category of wetness (1982, 1987, 1989, 1996, 1997 and 2003).

- The last phase (2008-2010) shows dry conditions. Humid conditions are founded with indices exceeding +1 . During the last two years, "very wet conditions are observed in all stations.

\section{DISCUSSION AND CONCLUSIONS}

The evolution of the rains in north-eastern of Tunisia is marked by the characteristic Mediterranean climate variability. The long period dry (1977-2001) is less marked than for the Morocco. It is distinguished by a regular return of humid conditions every two to three years. Finally, the return of the rains which is visible from 2002 is the most confirmed the scale of the central Maghreb.

For Moroccan rainfall, it is the persistence of droughts and their extension in time. After the wet period from 1970-1980, the drought is rife over a period of 27 years in this region. 1981 and 2007). Finally, the last phase of the series is clearly distinguished by records clues that may indicate the beginning of a new trend (2008, 2009 and 2010).

Analysis of rainfall data recorded in this large region of the South shore of the Mediterranean basin shows significant variability in this climate setting. This nature of the Mediterranean climate thus reflects the vulnerability of this area 'hot spot' to global climate change. This investigation also helped to highlight the severity of the great period of drought that hit the region between 1980 and 2007. During this period of scarcity, rainfall totals reached their lowest level in the Morocco (country most affected by the severity of the drastic conditions).

Finally, new rainfall conditions are recorded from 2002 in the two countries studied: they show a new climate trend. These conditions called "return of the wet period" are confirmed by the agricultural assessments of 2011-2012 and 2012-2013 (DEPF, 2012) and information on the rates of dams filling. This assumption is supported by the evidence of the impact of different global climate oscillations 
(North Atlantic Oscillation; El Niño Southern Oscillation) in most of continents and particularly on the African continent (López-Moreno \& al, 2011). Forecasts vary from one model to another, but an increase in precipitation and extreme weather events could take its place in the global dynamics of climate change (IPCC, 2007).

\section{REFERENCES}

1. IPCC (Intergovernmental Panel on Climate Change) (2007) Impacts, Adaptation \& Vulnerability, Cambridge University Press, Cambridge; http://www.ipcc.ch/;

2. IPCC (Intergovernmental Panel on Climate Change) GIEC. (2013), Changements climatiques en 2013, Les éléments scientifiques, résumé à l'intention des décideurs, service d'appui technique $d u$ groupe de travail I GTI, https://www.ipcc.ch/report/ar5/wg1/docs/WG1AR5_SPM_brochure_fr.pdf, 34.

3. Nouaceur, Z., Laignel, B., Turki, I. (2013), Changements climatiques au Maghreb : vers des conditions plus humides et plus chaudes sur le littoral algérien?, PhysioGéo, Volume 7, 2013; http://physio-geo.revues.org/3686 ; DOI : 10.4000/physiogeo.3686.

4. New, M., Todd, M., Hulme, M., Jones, P. (2001), Precipitation measurements and trends in the twentieh century, International Journal of Climatology, Volume 21, Issue 15:1889-1922.

5. Christensen, J.H., Hewitson, B., Busuioc, A., Chen, A., Gao, X., Held, I. \& al. (2007) Regional Climate Projections. In: Climate Change 2007: The physical Sciences Basis. Contribution of Working Group I to the Fourth Assessment Report of the Intergovernmental Panel on Climate Change, Solomon S, Qin D, Manning M, Chen Z, Marquis M, Averyt KB, Tignor M and HL Miller (eds.) Cambridge University Press: Cambridge, New York, 847-940; https://www.ipccwg1.unibe.ch/publications/wg1-ar4/ar4-wg1-chapter11.pdf.

6. Massei, N., Durand, A., Deloffre, J., Dupont, J.P., Valdes, D., Laignel, B. (2007) Investigating possible links between the North Atlantic Oscillation and rainfall variability in northwestern France over the past 35 years, Journal of Geophysical Research 112: D09121, DOI:10.1029/2005JD007000.

7. Tramblay, Y., Badi, W., Driouech, F., El Adlouni, S., Neppel, L., Servat, E. (2012) Climate change impacts on extreme precipitation in Morocco, Global and Planetary Change, $82-83: 104-114$

8. Boosy, D. (2013) La mousson en Inde est-elle exceptionnelle en 2013, Futura Sciences. http:// www.futura-sciences.com magazines environnement infos actu meteorologie mousson inde elle exceptionnelle 201347361.

9. Corner, A. (2014) Will record floods finally shift UK climate debate? http://www.newscientist.com/article/dn25061-will-record-floods-finally-shift-ukclimate-debate.html\#.UwTG-P15N8E.

10. Daoud, A. (2013) Retour d'expérience sur les inondations dans l'agglomération de Sfax (Tunisie méridionale) de 1982 à 2009 : de la prévention à la territorialisation du risque, Revue Géographique de l'Est, vol 53, 1-2, 1-14.

11. Direction des études et des prévisions financières - DEPF (2012), Note de conjoncture, 19, 23. 
12. Lopez Morino, J.I., Vicente Serrano, S.M., Moran Tejeda, E., Lorenzo Lacruz, J., Kenawy, A., Beniston, M. (2011) Effects of the North Atlantic Oscillation (NAO) on combined temperature and precipitation winter modes in the Mediterranean mountains: observed relationship and projections for the 21st century. Global and Planetary Change, vol. 77, 62-76. 